\title{
Digital orthodontic radiographic set versus cone-beam computed tomography: an evaluation of the effective dose
}

\author{
Lillian Atsumi Simabuguro Chinem¹, Beatriz de Souza Vilella², Cláudia Lúcia de Pinho Maurício³, \\ Lucia Viviana Canevaro ${ }^{3}$, Luiz Fernando Deluiz4, Oswaldo de Vasconcellos Vilella²
}

DOI: http://dx.doi.org/10.1590/2177-6709.21.4.066-072.oar

\begin{abstract}
Objective: The aim of this study was to compare the equivalent and effective doses of different digital radiographic methods (panoramic, lateral cephalometric and periapical) with cone-beam computed tomography (CBCT). Methods: Precalibrated thermoluminescent dosimeters were placed at 24 locations in an anthropomorphic phantom (Alderson Rando Phantom, Alderson Research Laboratories, New York, NY, USA), representing a medium sized adult. The following devices were tested: Heliodent Plus (Sirona Dental Systems, Bernsheim, Germany), Orthophos XG 5 (Sirona Dental Systems, Bernsheim, Germany) and i-CAT (Imaging Sciences International, Hatfield, PA, USA). The equivalent doses and effective doses were calculated considering the recommendations of the International Commission of Radiological Protection (ICRP) issued in 1990 and 2007. Results: Although the effective dose of the radiographic set corresponded to 17.5\% (ICRP 1990) and 47.2\% (ICRP 2007) of the CBCT dose, the equivalent doses of skin, bone surface and muscle obtained by the radiographic set were higher when compared to CBCT. However, in some areas, the radiation produced by the orthodontic set was higher due to the complete periapical examination. Conclusion: Considering the optimization principle of radiation protection, i-CAT tomography should be used only in specific and justified circumstances. Additionally, following the ALARA principle, single periapical radiographies covering restricted areas are more suitable than the complete periapical examination.
\end{abstract}

Keywords: Cone-beam computed tomography. Digital radiograph. Radiation dose.

Objetivo: o objetivo deste estudo foi comparar as doses equivalentes e efetivas absorvidas pelo mesmo receptor, quando exposto a diferentes exames radiográficos digitais (panorâmica, telerradiografia lateral e periapicais) e à tomografia computadorizada de feixe cônico (TCFC). Métodos: dosímetros termoluminescentes pré-calibrados foram colocados em 24 locais em um phantom antropomórfico (Alderson Rando Phantom, Laboratórios de Pesquisas de Alderson, New York, NY, EUA), o que representa um adulto de tamanho médio. Os seguintes equipamentos foram avaliados: Heliodent Plus (Sirona Dental Systems, Bernsheim, Alemanha), Orthophos XG 5 (Sirona Dental Systems, Bernsheim, Alemanha) e i-CAT (Imaging Sciences International, Hatfield, PA, EUA). As doses equivalentes e as doses efetivas foram calculadas tendo-se em conta as recomendações da Comissão Internacional de Proteção Radiológica (International Commission on Radiological Protection, ICRP), publicadas em 1990 e 2007. Resultados: embora a dose eficaz do set radiográfico tenha correspondido a 17,5\% (ICRP 1990) e 47,2\% (ICRP 2007) da dose da TCFC, as doses equivalentes na pele e superfícies ósseas e musculares desse set foram maiores, quando comparadas às da TCFC. Em algumas áreas, a radiação produzida pelo set de radiografias foi maior, devido à radiação do exame periapical completo. Conclusão: considerando-se o princípio da otimização da proteção radiológica, a tomografia computadorizada adquirida no tomógrafo i-CAT deve ser usada apenas em circunstâncias específicas e justificadas. Além disso, seguindo o princípio ALARA, radiografias periapicais unitárias de áreas pré-selecionadas são mais apropriadas do que o exame periapical completo.

Palavras-chave: Tomografia computadorizada de feixe cônico. Radiografia digital. Dose de radiação.

\footnotetext{
${ }^{1}$ Specialist in Orthodontics, Universidade Federal Fluminense (UFF), Niterói, Rio de Janeiro, Brazil.

${ }^{2}$ Professor, Graduate program in Orthodontics, Universidade Federal Fluminense (UFF), Niterói, Rio de Janeiro, Brazil.

${ }^{3}$ Professor, Graduate program in Radioprotection and Dosimetry, Instituto de Radioproteção e Dosimetria (IRD), Rio de Janeiro, Rio de Janeiro, Brazil.

${ }^{4}$ Professor, Graduate program in Radiology, Universidade Estácio de Sá (UNESA), Rio de Janeiro, Rio de Janeiro, Brazil.
}

Submitted: June 11, 2015 - Revised and accepted: February 21, 2016.
How to cite this article: Chinem LAS, Vilella BS, Mauricio CLP, Canevaro LV, Deluiz LF, Vilella OV. Digital orthodontic radiographic set versus cone-beam computed tomography: an evaluation of the effective dose. Dental Press J Orthod. 2016 July-Aug;21(4):66-72.

doi: http://dx.doi.org/10.1590/2177-6709.21.1.066-072.oar

» The authors report no commercial, proprietary or financial interest in the products or companies described in this article.

» Patients displayed in this article previously approved the use of their facial and intraoral photographs.

Contact address: Lillian Atsumi Simabuguro Chinem Rua Mário Santos Braga 30, 2o andar, sala 214 - Niterói, Rio de Janeiro, Brazil. E-mail: lillianatsumi@globo.com 


\section{INTRODUCTION}

The limitation of radiography due to its twodimensional representation of tridimensional structures is a well-known fact. ${ }^{1,2}$ In the last decades, twodimensional images were gradually replaced by tridimensional ones. Cone-beam computed tomography (CBCT) provides a high-resolution image that is similar to computed tomography, ${ }^{3}$ but at lower cost and radiation dose. ${ }^{4,5,6}$ Given these advantages, CBCT use is widespread in Dentistry nowadays, particularly for diagnosis, treatment planning and follow-up. ${ }^{7}$

On the other hand, the high prevalence of adolescents who seek orthodontic treatment goes against the fact that the radiation emitted by CBCT is greater than the radiation emitted by a radiographic device. The higher frequency of young patients results in a concern regarding radiation dose, as children seem to carry the brunt of radiation for a longer period of time than adults, and their developing organs are more sensitive to radiation effects. ${ }^{8}$

Furthermore, due to stochastic effects, of which probability of occurring is proportional to the radiation dose without a threshold, limits had to be established. The ALARA principle is usually applied as a reference. ${ }^{9}$

In order to control the radiation doses emitted by the devices and to allow evaluations and comparisons of different devices, the International Commission of Radiological Protection (ICRP) established values in 1990 and 2007. These values were applied to calculate the absorbed dose, the equivalent and the effective dose. Although studies have already compared different models and parameters, significant differences between models and between imaging protocols of the same device were observed. ${ }^{10,11}$

The aim of this study is to compare the equivalent and effective doses of different digital radiographic methods (panoramic, lateral cephalometric and periapical) with cone-beam computed tomography (CBCT) absorbed by the same receptor.

\section{MATERIAL AND METHODS \\ Calibration and selection of dosimeters}

Two types of thermoluminescent dosimeters (TLD) were employed in this study: TLD-100 Chip (Thermo Fisher Scientific Incorporation, Waltham, MA, USA) and TLD-100 Rod (Thermo Fisher Scientific Incorporation, Waltham, MA, USA). Due to the attenuation of radiation by the tissues, chip dosimeters were positioned on skin areas while rods dosimeters, more sensitive, were adapted in the holes inside the phantom. TLDs were prepared, calibrated and evaluated following the routine procedures of the Thermoluminescent Dosimetry Laboratory of Instituto de Radioproteção e Dosimetria (IRD), Brazil. Thereafter, they were preselected in groups with similar sensitivities (standard deviation of the mean value were lower than 5\%) after three Cs 137 free in air irradiations with electronic equilibrium. The air kerma values were of $1.0 \mathrm{mGy}$.

The selected dosimeters were wrapped in plastic, so as to protect them from dirt and moisture. Subsequently, each one of these plastic packs was placed in a specific location inside an Alderson Rando phantom in order to evaluate the organ/tissue equivalent dose. A total of 19 TLDs was chosen to measure the background dose.

\section{The location of dosimeters}

The dosimeters were positioned in 24 regions (Table 1) of a phantom that was composed by the skeleton of a medium sized male adult $(1.75 \mathrm{~m})$ covered with equivalent tissue material. The areas were selected according to Ludlow's methods ${ }^{6,12-15}$ and corresponded to radiosensitive organs, including eyes and pituitary gland. All dosimeters were placed inside the phantom by the same operator in order to reduce positioning variability.

\section{Protocols and parameters adopted}

The devices evaluated were Heliodent Plus (Sirona Dental Systems, Bernsheim, Germany), Orthophos XG 5 (Sirona Dental Systems, Bernsheim, Germany) and CBCT i-CAT (Imaging Sciences International, Hatfield, Pa, USA). Protocols for digital radiograph and CBCT parameters for examination of a medium sized male adult were adopted (Table 2). For the periapical examination, exposure time varied according to the region; whereas for the CBCT examination a field of view (FOV) of $22 \mathrm{~cm}$ was necessary in order to obtain the image of all structures.

The phantom was positioned according to the manufacturer's guidelines without the thyroid collar. Based on the doses obtained in other studies, ${ }^{12,16}$ and also to avoid underexposure and overexposure of the dosimeters, ten exposures for panoramic and lateral cephalometric radiographs, five exposures for periapical and one exposure for CBCT were performed. 
Table 1 - Location of thermoluminescent dosimeters in Alderson Rando phantom.

\begin{tabular}{|c|c|c|}
\hline Organ/Tissue & Location & TLDs \\
\hline \multirow{6}{*}{ Bone marrow } & Anterior calvarium & 1 \\
\hline & Posterior calvarium & 2 \\
\hline & Left calvarium & 3 \\
\hline & Center cervical spine & 12 \\
\hline & Right/left ramus & 10,11 \\
\hline & Right/left mandibular body & 14,15 \\
\hline \multirow{2}{*}{ Brain } & Mid brain & 7 \\
\hline & Pituitary fossa & 4 \\
\hline \multirow{2}{*}{ Eyes } & Right/left orbit & 5,6 \\
\hline & Right/left lens of eye & $21-24^{*}$ \\
\hline \multirow{3}{*}{ Salivary glands } & Right/left parotid & 8,9 \\
\hline & Right/left submandibular gland & 16,17 \\
\hline & Sublingual gland & 13 \\
\hline \multirow{2}{*}{ Thyroid } & Thyroid surface & $19 *$ \\
\hline & Midline thyroid & 18 \\
\hline \multirow{2}{*}{ Skin } & Right cheek & $25,26^{*}$ \\
\hline & Left back of neck & $27,28^{*}$ \\
\hline Esophagus & Pharyngeal-esophageal space & 20 \\
\hline
\end{tabular}

*Dosimeters positioned on the surface of the phantom. TLDs: thermoluminescent dosimeters.

Table 2 - Parameters adopted

\begin{tabular}{|c|c|c|c|c|}
\hline & FOV* & $\mathbf{k} \mathbf{V}^{* *}$ & $m A^{* * *}$ & Exposure time (s) \\
\hline Heliodent plus & Periapical & 70 & 7 & $0.25-0.4$ \\
\hline Orthophos XG 5 & Panoramic & 69 & 15 & 14.1 \\
\hline Orthophos XG 5 & Cephalometric & 80 & 14 & 9.4 \\
\hline i-CAT & $22 \mathrm{~cm}$ & 120 & $3-7$ & 40 \\
\hline
\end{tabular}

*Field of view. **Kilovoltage. *** Milliamperes.

\section{The equivalent and the effective doses}

The values obtained were divided by the number of repeated irradiations, so as to obtain the value per examination.

For the bone marrow, the equivalent dose was calculated based on the distribution of bone throughout the adult body. The mandible contains $1.3 \%$, the calvarium $11.8 \%$ and the cervical spine contains $3.4 \%$. The technique by Underhill et al was adopted to calculate the dose for the calvarium. For bone surface, a correction factor was applied:

Bone: muscle attenuation ratio $=$

$-0.0618 \times \mathrm{kV}$ peak $\times \frac{2}{3}+6.9406 . .^{17}$

The proportion of skin area in the head and neck region directly exposed during maxillofacial $\mathrm{CBCT}$ imaging is estimated as $5 \%$ of the total body. Muscle and lymphatic nodes are estimated to represent 5\%, esophageal tract 10\% and other tissues 100\%. ${ }^{12}$

The salivary glands began to be used in the effective dose calculation only in ICRP 2007. ${ }^{18}$ Their equivalent dose is obtained with the weighted average dose values of parotid, submandibular and sublingual glands.

The equivalent doses $\left(\mathrm{H}_{\mathrm{T}}\right)$ in these organ/tissues were calculated by the following formula:

$\mathrm{H}_{\mathrm{T}(\mu \mathrm{Sv}):} \mathrm{W}_{\mathrm{R}} \times \mathrm{D}_{\mathrm{T}}$

$\mathrm{W}_{\mathrm{R}}$ is the radiation weighting factor and its value is 1 for X-rays. $\mathrm{D}_{\mathrm{T}}$ is the mean absorbed dose in T. ${ }^{19}$

The effective dose (E), proposed by ICRP $1990,{ }^{18}$ is a reliable clinical and standardized measure of the biological effects of radiation, although previous studies have 
demonstrated limitations. ${ }^{20}$ The effective dose defined to estimate an average whole body human radiation risk is calculated with the following formula:

$\mathrm{E}=\sum \mathrm{w}_{\mathrm{T}} \mathrm{X} \mathrm{H}_{\mathrm{T}}{ }^{18}$

$\mathrm{W}_{\mathrm{T}}$ is the weighting factor of the organ or tissue $\left({ }_{T}\right)$ and is related to its radiation sensitivity. Both tissue weighting factors of ICRP 60 and ICRP 103 (1990 and 2007) applied in this study are presented in Table 3.

ICRP $103(2007)^{18}$ increased the number of organs/tissues with $\mathrm{w}_{\mathrm{T}}$ values, including brain and salivary glands, and the number of remainder tissues increased to 14 . Only lymphatic nodes, muscles, extrathoracic airways and oral mucosa were exposed during the tests (Table 4).

The new recommendations stated that brain and salivary glands received factors of 0.01 and 0.1 , respectively. The oral mucosa equivalent dose was calculated by the salivary glands and mandibular ramus and body with a conservative estimate of $100 \% .^{14}$

\section{RESULTS}

The obtained values of the equivalent and effective doses are listed in Table 5. The lowest equivalent doses were obtained in lateral cephalometric radiograph, followed by panoramic, periapical and CBCT. Considering thyroid equivalent doses, it was observed that their values were lower in lateral cephalometric and periapical examinations, and higher in CBCT.

By adding salivary glands to the calculations of effective doses, their values increased considerably. The glands and the remainder tissues were the main contributors to the effective dose in lateral cephalometric and panoramic radiographs. The effective doses using values recommended by the ICRP $60(1990)^{19}$ correspond to $48 \%, 24.7 \%, 23.8 \%$ and $66.6 \%$ of the doses calculated with the recommendations of the ICRP $103(2007)^{18}$ for cephalometric, panoramic, periapical and CBCT, respectively. These results corroborate those of other studies. ${ }^{6,12}$

Table 3 - Estimated percentage of tissue irradiated and dosimeters used to calculate mean absorbed dosage.

\begin{tabular}{|c|c|c|}
\hline Organ/Tissue & Fraction irradiated $(\%)$ & TLD \\
\hline Bone marrow & 16.5 & \\
\hline Mandible & 1.3 & $10,11,14,15$ \\
\hline Calvarium & 11.8 & $1-3$ \\
\hline Cervical spine & 3.4 & 12 \\
\hline Thyroid & 100 & 18,19 \\
\hline Esophagus & 10 & 20 \\
\hline Skin & 5 & $21-28$ \\
\hline Bone surface & 16.5 & \\
\hline Mandible & 1.3 & $10,11,14,15$ \\
\hline Calvarium & 11.8 & $1-3$ \\
\hline Cervical spine & 3.4 & 12 \\
\hline Salivary glands & 100 & \\
\hline Parotid & 100 & 8,9 \\
\hline Submandibular & 100 & 16,17 \\
\hline Sublingual & 100 & 13 \\
\hline Brain* & 100 & 4,7 \\
\hline \multicolumn{3}{|l|}{ Remainder } \\
\hline Brain** & 100 & 4,7 \\
\hline Lymphatic nodes* & 5 & $1-12$ \\
\hline Muscles*,** & 5 & $1-12$ \\
\hline Extrathoracic airway* & 100 & $5,6,8-12$ \\
\hline Oral mucosa* & 100 & $8-11,13$ \\
\hline
\end{tabular}

*ICRP 2007 recommendations, ${ }^{* \star \mid C R P} 1990$ recommendations. TLD: thermoluminescent dosimeter. 
Table 4 - Tissue weighting factors - ICRP 1990 and 2007 recommendations.

\begin{tabular}{ccc}
\hline Organ/Tissue & $\mathbf{W}_{\mathrm{T}} \mathbf{1 9 9 0}$ & $\mathbf{W}_{\mathrm{T}} \mathbf{2 0 0 7}$ \\
\hline Bone marrow & 0.12 & 0.12 \\
\hline Breast & 0.05 & 0.12 \\
\hline Colon & 0.12 & 0.12 \\
\hline Lung & 0.12 & 0.12 \\
\hline Stomach & 0.12 & 0.12 \\
\hline Bladder & 0.05 & 0.04 \\
\hline Esophagus & 0.05 & 0.05 \\
\hline Gonads & 0.20 & 0.08 \\
\hline Liver & 0.05 & 0.04 \\
\hline Thyroid & 0.05 & 0.05 \\
\hline Bone surface & 0.01 & 0.01 \\
\hline Brain & Remainder & 0.01 \\
\hline Salivary glands & - & 0.01 \\
\hline Skin & 0.01 & 0.01 \\
\hline Remainder & $0.05 *$ & $0.10 * *$ \\
\hline
\end{tabular}

*Adrenals, brain, upper large intestine, small intestine, kidney, muscle, pancreas, spleen, thymus and uterus. ${ }^{* *}$ Adrenals, extrathoracic region, gall bladder, heart, kidneys, lymphatic nodes, muscle, oral mucosa, pancreas, prostate small intestine, spleen, thymus and uterus.
The equivalent and effective doses obtained by the radiographic set were summed up and the percentages between these values and the CBCT values were calculated (Table 5). Although the effective dose of the radiographic set corresponded to $17.5 \%$ (ICRP 1990) and 47.2\% (ICRP 2007) of the CBCT dose, the equivalent doses of skin, bone surface and muscle obtained by the radiographic set were higher when compared to CBCT.

\section{DISCUSSION}

In dosimetry, several factors must be considered: the phantom used (made from bones or just equivalent tissue material), number and location of dosimeters, type of device tested and its parameters (voltage $[\mathrm{kV}]$, amperage $[\mathrm{mA}]$, time of exposure, field of view [FOV] and voxel). ${ }^{10}$ Different combinations lead to different doses. Due to many variables, there are no appropriate parameters to compare these results, especially in relation to effective doses of radiographs and CBCT. Furthermore, in order

Table 5 - Mean of equivalent doses ( $\mu$ Sv) of each organ or tissue, effective doses ( $\mu$ Sv) and percentage of equivalent and effective doses of all devices compared to CBCT.

\begin{tabular}{|c|c|c|c|c|c|c|}
\hline Organ/Tissue & Cephalometric & Panoramic & Periapical & СBCT & Radiographic set & $\begin{array}{l}\text { Radiographic set/ } \\
\text { CBCT (\%) }\end{array}$ \\
\hline Thyroid & 5.1 & 34.5 & 1.1 & 388.5 & 40.7 & 10.5 \\
\hline Bone marrow & 3.3 & 21.4 & 66.3 & 279.6 & 91 & 32.5 \\
\hline Esophagus & 0.7 & 3.4 & 10 & 89.7 & 14.1 & 15.7 \\
\hline Skin & 1 & 36.2 & 0.7 & 0.2 & 37.9 & 18950.0 \\
\hline Bone surface & 12.1 & 87.7 & 3268.4 & 556.4 & 3368.2 & 605.4 \\
\hline Salivary glands & 26.4 & 359.1 & 932.2 & 1908.2 & 1317.7 & 69.1 \\
\hline Brain $^{* *}$ & 14 & 33.9 & 139.7 & 2985.3 & 187.6 & 6.3 \\
\hline \multicolumn{7}{|l|}{ Remainder } \\
\hline Brain* & 14 & 33.9 & 139.7 & 2985.3 & 187.6 & 6.3 \\
\hline Lymphatic nodes** & 1.3 & 18 & 46.6 & 95.4 & 65.9 & 69.1 \\
\hline Extrathoracic airways ${ }^{* *}$ & 26.4 & 359.1 & 932.2 & 1908.2 & 1317.7 & 69.1 \\
\hline Muscles* ${ }^{* *}$ & 1 & 5.6 & 70.4 & 62.3 & 77 & 123.6 \\
\hline Oral mucosa** & 23.2 & 316 & 839.7 & 1813.1 & 1178.9 & 65.0 \\
\hline Effective dosage ICRP 90 & 1.2 & 6.7 & 16.5 & 139.2 & 24.4 & 17.5 \\
\hline Effective dosage ICRP 07 & 2.5 & 27.1 & 69.1 & 208.9 & 98.7 & 47.2 \\
\hline
\end{tabular}

*ICRP 1990; **ICRP 2007. 
to allow comparison between different studies, a standard methodology should be established.

A wide variation of effective doses was observed in different studies when evaluating CBCT scans. When comparing the same i-CAT model, different results were

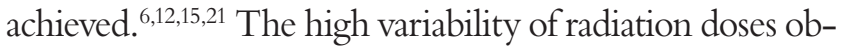
tained compromises comparisons among different devices.

Studies that evaluated current models, such as i-CAT Next Generation and i-CAT FLX, found effective doses of $182.1 \mu \mathrm{Sv}^{15}$ and $69.2 \mu \mathrm{Sv}{ }^{21}$ respectively. The reduction of FOV down to $17 \mathrm{~cm}$ and exposure time to 3.7 seconds may have contributed to reduce the effective dose, which reached about 38.9\% when the results of these studies were compared with those of i-CAT FLX.

However, it was reported that the average distance between nasion and menton was $12.28 \mathrm{~cm} \cdot{ }^{22}$ While a multiethnic population presents much more variation, anterior facial height may reach greater values than these ones. Therefore, to the reduced field of view, even in the extended field of view protocol, some essential structures may be cut out of the image obtained.

The effective dose measured in i-CAT in the present study was greater than the sum of the effective doses of all radiographic examinations routinely required for orthodontic treatment. One reason for this difference might be the radiographic devices used in the study, which produce digital images with lower radiation doses. Additionally, i-CAT is a large volume tomographic device with extended FOV. The area exposed during examination is, therefore, increased.

The doses obtained in this study were higher in all devices because a lead apron was not used. The highest equivalent doses found were in the regions of the thyroid, brain and eyes. When a thyroid apron is used, there is a reduction of $48.7 \%$ in the dosage of the thyroid, and $41.7 \%$ in the dosage of the esophagus. ${ }^{23}$ Examinations with a large FOV showed a reduction of $61 \% .^{24}$ Therefore, the use of lead aprons should not be overlooked.

Additionally, the geometrical position of these organs in relation to the X-ray beam may have influenced the results. In i-CAT, due to the largest FOV, the organ is closer to the X-ray center of the beam.

The effective dose of the radiographic set corresponded to less than a half of the dose calculated for CBCT. On the other hand, the equivalent doses of skin, bone surface and muscle were higher (Table 5). The periapical examination was the most responsible for the highest dose. It could be due to proximity of dosimeters to the molars area. Therefore, to follow the ALARA ${ }^{9}$ principle (as low as possible radiation), the orthodontist should not request full periapical examination. Instead, single periapical radiographs covering restricted areas are more suitable.

Although the equivalent and effective doses of CBCT scans are high when compared to X-rays, the doses of multidetector CT scanners, used routinely for medical examinations, are dozens of times higher. ${ }^{13,25}$ Furthermore, it is estimated that the population is exposed to an average dose of natural radiation of $2400 \mu \mathrm{Sv}$ per year, ${ }^{26}$ and that the risk of developing cancer from exposure during CBCT examination is between 1:100.000 and 1:350.000 for adults. ${ }^{19}$

Moreover, tomography accepts the capture of a range of images otherwise inaccessible to radiography, whenever more in-depth information is needed about the patient. Nevertheless, based on the results of the current and other studies, CBCT examination with the i-CAT device should be indicated only in special cases and should not be used routinely.

\section{CONCLUSION}

The effective doses produced by i-CAT were higher than the doses generated by the digital radiographs of the orthodontic set. However, in some areas, the radiation produced by the orthodontic set was higher due to complete periapical examination. Replacing radiographs with tomographic images generated by this device goes against the principle of ALARA and should be carried out only in specific cases. Furthermore, single periapical radiographs covering restricted areas are more suitable than complete periapical examination.

\section{Acknowledgements}

We would like to thank Instituto de Radioproteção e Dosimetria (IRD) and Centro de Ensino e Diagnóstico em Tomografia (CEDT) for all the support.

\section{Author contributions}

Study conception/design: BSV, CLPM, LVC, OVV; Data acquisition, analysis or interpretation: LASC, CLPM, LVC, LFD; Writing the article: LASC; Critical revision of the article: BSV, CLPM, OVV; Final approval of the article: OVV; Obtained funding: LASC, BSV, CLPM, LVC, LFD, OVV. 


\section{REFERENCES}

1. Adams GL, Gansky SA, Miller AJ, Harrell WE Jr, Hatcher DC. Comparison between traditional 2-dimensional cephalometry and a 3-dimensional approach on human dry skulls. Am J Orthod Dentofacial Orthop. 2004 Oct:126(4):397-409.

2. Tsao DH, Kazanoglu A, McCasland JP. Measurability of radiographic images. Am J Orthod. 1983 Sept;84(3):212-6.

3. Swennen GR, Schutyser F. Three-dimensional cephalometry: spiral multi-slice vs cone-beam computed tomography. Am J Orthod Dentofacial Orthop. 2006 Sept:130(3):410-6

4. White SC, Pharoah MJ. The evolution and application of dental maxillofacial imaging modalities. Dent Clin North Am. 2008 Oct;52(4):689-705, v.

5. Yamamoto K, Ueno K, Seo K, Shinohara D. Development of dento-maxillofacial cone beam X-ray computed tomography system. Orthod Craniofac Res. 2003:6 Suppl 1:160-2

6. Roberts JA, Drage NA, Davies J, Thomas DW. Effective dose from cone beam CT examinations in dentistry. Br J Radiol. 2009 Jan;82(973):35-40

7. Scarfe WC, Farman AG, Sukovic P. Clinical applications of cone-beam computed tomography in dental practice. J Can Dent Assoc. 2006 Feb;72(1):75-80

8. Halazonetis DJ. From 2-dimensional cephalograms to 3-dimensional computed tomography scans. Am J Orthod Dentofacial Orthop. 2005 May;127(5):627-37.

9. Farman AG. ALARA still applies. Oral Surg Oral Med Oral Pathol Oral Radio Endod. 2005 Oct;100(4):395-7.

10. Helmrot E, Thilander-Klang A. Methods for monitoring patient dose in dental radiology. Radiat Prot Dosimetry. 2010 Apr-May:139(1-3):303-5.

11. Qu XM, Li G, Ludlow JB, Zhang ZY, Ma XC. Effective radiation dose of ProMax 3D cone-beam computerized tomography scanner with different dental protocols. Oral Surg Oral Med Oral Pathol Oral Radiol Endod. 2010 Dec;110(6):770-6.

12. Ludlow JB, Davies-Ludlow LE, Brooks SL, Howerton WB. Dosimetry of 3 CBCT devices for oral and maxillofacial radiology: CB Mercuray, NewTom 3G and i-CAT. Dentomaxillofac Radiol. 2006 July; 35(4):219-26

13. Ludlow JB, Ivanovic M. Comparative dosimetry of dental CBCT devices and 64-slice CT for oral and maxillofacial radiology. Oral Surg Oral Med Oral Pathol Oral Radiol Endod. 2008 July;106(1):106-14.

14. Ludlow JB. A manufacturer's role in reducing the dose of cone beam computed tomography examinations: effect of beam filtration. Dentomaxillofac Radiol. 2011 Feb;40(2):115-22
15. Grünheid T, Kolbeck Schieck JR, Pliska BT, Ahmad M, Larson BE. Dosimetry of a cone-beam computed tomography machine compared with a digital X-ray machine in orthodontic imaging. Am J Orthod Dentofacial Orthop. 2012 Apr:141(4):436-43

16. Garcia Silva MA, Wolf U, Heinicke F, Gründler K, Visser H, Hirsch E. Effective dosages for recording Veraviewepocs dental panoramic images: analog film, digital, and panoramic scout for CBCT. Oral Surg Oral Med Oral Pathol Oral Radiol Endod. 2008 Oct:106(4):571-7

17. Statistics NBO. Physical aspects of irradiation. Washington, DC: US Government Printing Office; 1964

18. International Commission on Radiological Protection. The 2007 Recommendations of the International Commission on Radiological Protection. ICRP publication 103. Ann ICRP. 2007:37(2-4):1-332.

19. International Commission on Radiological Protection. 1990 Recommendations of the International Commission on Radiological Protection. Ann ICRP. 1991;21(1-3):1-201.

20. Loubele M, Bogaerts R, Van Dijck E, Pauwels R, Vanheusden S, Suetens P, et al. Comparison between effective radiation dose of CBCT and MSCT scanners for dentomaxillofacial applications. Eur J Radiol. 2009 Sept:71(3):461-8.

21. Ludlow JB, Walker $C$. Assessment of phantom dosimetry and image quality of i-CAT FLX cone-beam computed tomography. Am J Orthod Dentofacial Orthop. 2013 Dec;144(6):802-17.

22. Silva MBG, Gois BC, Sant'Anna EF. Evaluation of the reliability of measurements in cephalograms generated from cone beam computed tomography. Dental Press J Orthod. 2013 July-Aug:18(4):53-60

23. Qu XM, Li G, Sanderink GC, Zhang ZY, Ma XC. Dose reduction of cone beam CT scanning for the entire oral and maxillofacial regions with thyroid collars. Dentomaxillofac Radiol. 2012 July:41(5):373-8.

24. Qu X, Li G, Zhang Z, Ma X. Thyroid shields for radiation dose reduction during cone beam computed tomography scanning for different oral and maxillofacial regions. Eur J Radiol. 2012 Mar:81(3):e376-80.

25. Silva MA, Wolf U, Heinicke F, Bumann A, Visser H, Hirsch E. Cone-beam computed tomography for routine orthodontic treatment planning: a radiation dose evaluation. Am J Orthod Dentofacial Orthop. 2008 May;133(5):640.e1-5

26. UNSCEAR 2000. The United Nations Scientific Committee on the Effects of Atomic Radiation. Health Phys. 2000:79(3):314. 